\title{
Increased Cyclic AMP Levels Enhance IL-1 $\alpha$ and IL-1 $\beta$ mRNA Expression and Protein Production in Human Myelomonocytic Cell Lines and Monocytes
}

\author{
Sun-sang J. Sung and Jay A. Walters \\ Departments of Radiation Oncology and Microbiology and Immunology, and Massey Cancer Center, \\ Medical College of Virginia, Virginia Commonwealth University, Richmond, Virginia 23298
}

\begin{abstract}
The effects of increasing intracellular cAMP levels on IL-1 $\alpha$ and IL-1 $\beta$ mRNA expression and IL-1 production in human monocytes and nonlymphoid hematopoietic cell lines were examined. Peripheral monocytes and myelomonocytic cell lines could be stimulated by LPS or phorbol myristate acetate (PMA) to express IL-1 mRNA. Dibutyryl cAMP, 8-bromocAMP, forskolin, cholera toxin, $\mathrm{PGE}_{1}$, and $\mathrm{PGE}_{2}$ synergized with PMA or LPS to increase the accumulation in cell lines of IL-1 $\alpha$ mRNA by up to 50-fold and that of IL-1 $\beta$ mRNA by 10to 20-fold compared to LPS or PMA alone. This increase in IL-1 $\alpha$ and IL-1 $\beta$ mRNA accumulation was more modest in monocytes. The synergistic stimulation was due to enhanced IL-1 gene transcription rate rather than increased IL-1 mRNA stability. Despite this marked increase in IL-1 mRNA accumulation, IL-1 protein synthesis in these cells was increased by only twofold. Thus, IL-1 synthesis in monocytes and myelomonocytic cell lines is under stringent translational control. ( $J$. Clin. Invest. 1991.88:1915-1923.) Key words: prostaglandins • forskolin • cholera toxin • transcription rate $\bullet$ mRNA stability
\end{abstract}

\section{Introduction}

IL-1 is an important mediator in inflammatory and other immunological responses (see review, reference 1). The primary hematopoietic cell type responsible for IL-1 synthesis is the macrophage. The regulation of IL-1 synthesis is complex, and many aspects of this regulation are poorly understood. Two genes, both located on human chromosome 2 , encode the two active forms of IL-1, IL- $1 \alpha$ and IL- $1 \beta$, which share $25 \%$ in amino acid homology, bind to the same surface receptors $(2,3)$, and exert identical biological effects. Both IL- $1 \alpha$ and IL- $1 \beta$ are synthesized as cytosolic $31-33-\mathrm{kD}$ precursor proteins with no signal peptide $(1,4)$. Recent evidence suggests that these cytosolic precursors are secreted by macrophages (5) and cleaved by pre-IL-1 convertase activities (6) to the biologically active 17.5 $\mathrm{kD}$ form. IL-1 secretion does not seem to occur via the conventional endoplasmic reticulum-Golgi route and the pathway for IL-1 secretion is still unidentified. Besides transcriptional regulation, IL-1 synthesis is regulated posttranscriptionally (7-9),

Address correspondence to Dr. Sun-sang J. Sung, Department of Radiation Oncology, Virginia Commonwealth University, Box 58, MCV Station, Richmond, VA 23298-0058.

Received for publication 7 September 1990 and in revised form 29 July 1991.

J. Clin. Invest.

(C) The American Society for Clinical Investigation, Inc.

0021-9738/91/12/1915/09 \$2.00

Volume 88, December 1991, 1915-1923 either at the translational level, like tumor necrosis factor $(\mathrm{TNF})^{1}(10)$, or at the secretory level (8).

Elevation of intracellular cAMP is an important transmembrane-signaling mechanism for regulating the synthesis of many proteins (11). cAMP has been shown to play important roles in regulating IL-1 biosynthesis. However, results on the effects of intracellular cAMP elevation on IL-1 synthesis are conflicting. IL-1 and granulocyte-macrophage colony stimulating factor (GM-CSF), both of which induce intracellular cAMP elevation $(12,13)$, stimulate IL-1 production by human peripheral mononuclear cells (14), endothelial cells (15), and granulocytes (16). In addition, induction of intracellular cAMP elevation has also been shown to increase the release of IL-1 bioactivity (17) and cause no change in the level of cell-associated IL-1 (18) in LPS-stimulated monocytes. On the other hand, agents such as $\mathrm{PGE}_{2}$ and cholera toxin that also increase intracellular cAMP have been shown to inhibit the release of biologically active IL-1 by enterotoxin-stimulated human monocytes (7) and LPS-stimulated mouse peritoneal macrophages (19) without decreasing the IL-1-mRNA levels in these cells. The recent cloning and characterization of an IL-1 receptor antagonist (20), a macrophage product, further cloud the issue because of the antagonist's ability to interfere in IL-1 bioassays.

In an effort to clarify the role of CAMP in the regulation of IL-1 biosynthesis, and to further understand the biochemical basis of this regulation, we have examined the effects of cAMP analogues and adenylate cyclase stimulants on IL- $1 \alpha$ and IL- $1 \beta$ mRNA expression, and IL-1 synthesis in human myelomonocytic cell lines and monocytes. Our results showed that cAMP analogues and adenylate cyclase stimulants were by themselves incapable of initiating IL-1-mRNA transcription in these cells. However, these drugs were synergistic with phorbol myristate acetate (PMA) or LPS to increase markedly in cell lines and more modestly in fresh monocytes the steady-state mRNA levels and gene transcription rates of both IL- $1 \alpha$ and IL-1 $\beta$. Paradoxically, despite these increases in IL-1 mRNA levels, the IL-1 protein synthesis rate increased only two- to threefold. Thus, IL-1 synthesis is under translational control during cAMP stimulation. Furthermore, these results suggest that IL-1 synthesis in monocytes is autoregulated not only by cytokines such as TNF and IL-1, but also by prostaglandins produced by the same cells synthesizing IL-1.

\section{Methods}

Chemicals. PMA, $N^{6}, 2^{\prime}$-dibutyryl-cAMP (dBcAMP), 8-bromo-cAMP, LPS, indomethacin, and actinomycin D were from Sigma Chemical

1. Abbreviations used in this paper: dBcAMP, $N^{6}, 2^{\prime}$-dibutyryl-cAMP; GM-CSF, granulocyte-macrophage CSF; PD, PBS without $\mathrm{Ca}^{2+}$ and $\mathrm{Mg}^{2+} ; \mathrm{TNF}$, tumor necrosis factor. 
Co. (St. Louis, MO). Forskolin, $\mathrm{PGE}_{1}, \mathrm{PGE}_{2}, \mathrm{PGF}_{2 \alpha}$, and cholera toxin were from Calbiochem-Behring Corp. (San Diego, CA). Ficoll-Paque, Percoll and protein A-Sepharose were from Pharmacia LKB Biotechnology, Inc. (Piscataway, NJ). Rabbit anti-goat IgG antibody was from Organon Teknika-Cappel (Malvern, PA). The sources of other cell culture and molecular biology reagents have been described (21).

Cells. The sources and characteristics of the cell lines ML-1, KG-1, U-937, HL-60, and HEL have been described (22). Monocytes were isolated from buffy coats provided by the Oklahoma Blood Institute (Oklahoma City, OK) or the Richmond Metropolitan Blood Service (Richmond, VA) by centrifugation on a Ficoll-hypaque cushion followed by a continuous Percoll gradient as described (22). Endotoxinfree PBS, PBS without $\mathrm{Ca}^{2+}$ and $\mathrm{Mg}^{2+}(\mathrm{PD}), 100 \times$ glutamine-penicillin-streptomycin solution, RPMI 1640, and low endotoxin FCS ([endotoxin] $<0.006 \mathrm{ng} / \mathrm{ml}$ ) used in monocyte experiments were obtained from Irvine Scientific (Santa Ana, CA). Isolated monocytes ( $\sim 90 \%$ pure by Giemsa-Wright staining) were cultured in baked Teflon dishes $\left(180^{\circ} \mathrm{C}\right.$ overnight). All cells were cultured in RPMI 1640 with $10 \% \mathrm{FCS}, 50 \mathrm{U} / \mathrm{ml}$ penicillin, $50 \mu \mathrm{g} / \mathrm{ml}$ streptomycin sulfate and 2 $\mathrm{mM}$ glutamine. Cell viabilities were determined by trypan blue (21) and were $>95 \%$ at the end of drug treatments.

Northern blot analysis. Total RNA was isolated by ultracentrifugation through a $\mathrm{CsCl}$ cushion and poly(A) ${ }^{+}$RNA was selected by oligo $(d T)$ cellulose as described (23). Following RNA fractionation in formaldehyde gels, Northern blots were performed as described (21). The absorbance intensities of specific bands on autoradiograms were quantitated with either a Loats Digital Video Imaging System (Westminster, MD) or a Shimadzu TLC scanning assembly equipped with a CS910 scanner connected to a C-R1A Chromatopac integrator (Shimadzu Scientific Instruments, Inc., Columbia, MD). Blots were exposed to multiple Kodak XK-1 films with sequential two- or threefold exposures and underexposed bands within the linear range were quantitated. Longer exposures were adjusted for radioactive decay as described (24). The relative intensities are the ratios of the absolute intensities of IL-1 bands in the samples against that of the IL-1 band in RNA from cells treated with PMA or LPS alone.

DNA probes. cDNA clones of human triose-phosphate isomerase and IL-1 $\beta$ were obtained from the American Type Culture Collection (Rockville, MD). The IL-1 $\beta$ probe was confirmed by dideoxy sequencing (23). The human IL-1 $\alpha$ and HLA-B7, and the chicken $\beta$-actin probes were generous gifts of Dr. D. Cosman (Immunex Research and Development Corp., Seattle, WA), Dr. S. Weissman (Yale University, New Haven, CT), and Dr. M. Kirschner (University of California, San Francisco, CA), respectively. The IL-1 $\alpha$ cDNA gave the predicted restriction fragments. A 26 mer oligonucleotide probe was used to quantitate the 28S rRNA on blots (25).

cAMP determination. Cells incubated with the indicated stimulants were pipetted into 3-4 vol of ice-cold PD at various time points. After sedimentation by centrifugation at $250 \mathrm{~g}$, the cells were lysed in $1 \mathrm{ml}$ of cold 10\% TCA. The acid-soluble fraction was extracted four times with equal volumes of ether and lyophilized. The cAMP content of the samples was determined by assaying aliquots of the redissolved residue with radioimmunoassay kits using ${ }^{125}$ I-labeled cAMP as tracer (Amersham Corp., Arlington Heights, IL).

$m R N A$ decay determination. Cells at $0.5-2 \times 10^{6} / \mathrm{ml}$ were preincubated in medium containing PMA alone $(3 \mathrm{ng} / \mathrm{ml})$ or PMA plus dBcAMP $(0.5 \mathrm{mM})$ for the appropriate time periods. They were collected, washed three times with ice-cold PD, and aliquoted at 20-30 $\times 10^{6}$ cells/sample $\left(2 \times 10^{6}\right.$ cells $\left./ \mathrm{ml}\right)$ in prewarmed medium containing $10 \mu \mathrm{g} / \mathrm{ml}$ actinomycin $\mathrm{D}$ and various drugs as indicated. At the indicated time points, samples were pipetted into $2-3 \mathrm{vol}$ of ice-cold $\mathrm{PD}$ and cooled on ice for $10 \mathrm{~min}$. Cells were collected by centrifugation and lysed in guanidinium-thiocyanate solution (23) for RNA isolation. Decay curves were fitted by linear regression using the computer program SigmaPlot (Jandel Scientific, Corte Madera, CA).

Nuclear run-on assays. Transcription rate determination by nuclear run-on was performed as described by Nevins (26). The run-on reaction was performed at $30^{\circ} \mathrm{C}$ using $150-250 \mu \mathrm{Ci}$ of $\left[\alpha-{ }^{32} \mathrm{P}\right] \mathrm{UTP}(800$ $\mathrm{Ci} / \mathrm{mmol}$; New England Nuclear, Boston, MA) and 3-5 $\times 10^{7}$ nuclei per reaction for ML-1 cells, and 1-2 $\times 10^{7}$ nuclei per reaction for monocytes. After digestion with RNase-free DNase I (Promega Biotec, Madison, WI) and proteinase K (Boehringer Mannheim, Indianapolis, IN), the reaction mixture was precipitated twice in $2 \mathrm{M} \mathrm{NH}_{4} \mathrm{OAc}$ and $70 \%$ ethanol to remove free nucleotides (27). The labeled RNA was used to hybridize for 36-48 $\mathrm{h}$ to nylon membranes slot-blotted with probes $(5 \mu \mathrm{g} / \mathrm{slot})$ according to the manufacturer's procedures (Schleicher \& Schull, Keene, NH). Specific immobilized run-off RNA was visualized by autoradiography and quantitated as described previously (24).

Immunoprecipitation of $I L-1$. Monocytes or ML-1 cells were washed three times in PD and incubated for various time periods in methionine-free RPMI 1640 (Gibco Laboratories, Grand Island, NY) containing $50 \mu \mathrm{Ci} / \mathrm{ml}\left[{ }^{35} \mathrm{~S}\right]$ methionine $(>1,000 \mathrm{Ci} / \mathrm{mmol}$; Amersham Corp., Arlington Heights, IL), $2 \mathrm{mM}$ glutamine, $50 \mu \mathrm{g} / \mathrm{ml}$ streptomycin, $50 \mathrm{U} / \mathrm{ml}$ penicillin and $10 \%$ dialysed FCS. LPS-free labeling medium was prepared by passing the labeling mixture through a polymyxin B-agarose column (Sigma Chemical Co., St. Louis, MO). Labeled cells and supernatants were separated by low speed centrifugation $(250 \mathrm{~g}, 10 \mathrm{~min})$. Supernatants were cleared of debris by centrifugation at $40,000 \mathrm{~g}$ for $30 \mathrm{~min}$. Immunoprecipitation was performed essentially as described (22). Cell lysates or supernatants were incubated with $100 \mu \mathrm{l}$ of $1000 \times$ diluted goat anti-human IL-1 $\alpha$ or anti-human IL-1 $\beta$ antiserum (gifts of Dr. R. Chizzonite, Hoffmann-La Roche, Nutley, $\mathrm{NJ})$ for $30 \mathrm{~min}$., followed by overnight rocking with $30 \mu \mathrm{l}$ of affinitypurified rabbit anti-goat IgG antibody bound to protein A-Sepharose. The IL- $1 \alpha$ and IL-1 $\beta$ antibodies do not cross-react with each other and their titers are $10^{5}$ and $5 \times 10^{4}$ (dilutions which give $O_{492}$ of 1.5 in ELISA tests), respectively. Immunoprecipitated proteins were separated on a discontinuous 15\% SDS-polyacrylamide gel. Pharmacia low molecular weight markers and Boehringer Mannheim Combithek were used as molecular weight standards.

\section{Results}

cAMP analogues and adenylate cyclase stimulants synergized with LPS and PMA to increase IL-1 $\alpha$ and IL-1 $\beta$ mRNA accumulation in human myelomonocytic cell lines. Five nonlymphoid hematopoietic cell lines were examined for their ability to express IL- $1 \alpha$ and IL- $1 \beta$ mRNA. IL- 1 mRNA's were undetectable in these cells in the absence of stimulation. The myeloid cell lines ML-1, KG-1, and HL- 60 could be stimulated by LPS or PMA to express both IL- $\alpha$ and IL- $1 \beta$ mRNAs. The monocytic cell line U-937 could likewise be stimulated to express IL- $1 \beta$, but not IL- $1 \alpha$ mRNA. The erythroid cell line HEL did not express either IL-1 mRNA upon stimulation. The myeloid cell line ML-1, which expressed the highest levels of IL- $1 \alpha$ and IL- $1 \beta$ mRNA, and the monocytic cell line U-937 were chosen for further studies.

In ML-1 cells, dBcAMP, forskolin, cholera toxin, and $\mathrm{PGE}_{2}$, when used alone, did not stimulate IL-1 mRNA expression (not shown). However, each of the drugs was synergistic with LPS in increasing both IL- $1 \alpha-$ and IL- $1 \beta-$ mRNA accumulation (Fig. $1 A$ ). dBcAMP was the most effective. It synergized with LPS to increase IL- $1 \alpha-$ and IL- $1 \beta-$ mRNA accumulation by 38 - and 48-fold, respectively, over that in cells treated with LPS alone. The synergistic increase of 8-bromo-cAMP at $1 \mathrm{mM}$, cholera toxin at $0.2-5 \mu \mathrm{g} / \mathrm{ml}, \mathrm{PGE}_{2}$ at $0.3-10 \mu \mathrm{M}$, and $\mathrm{PGE}_{1}$ at $10 \mu \mathrm{M}$ with LPS was 10 - to 20 -fold for the accumulation of both IL- $1 \alpha$ and IL- $1 \beta$ mRNA's. Forskolin showed the weakest stimulation with only a threefold elevation of IL- $1 \alpha-$ 

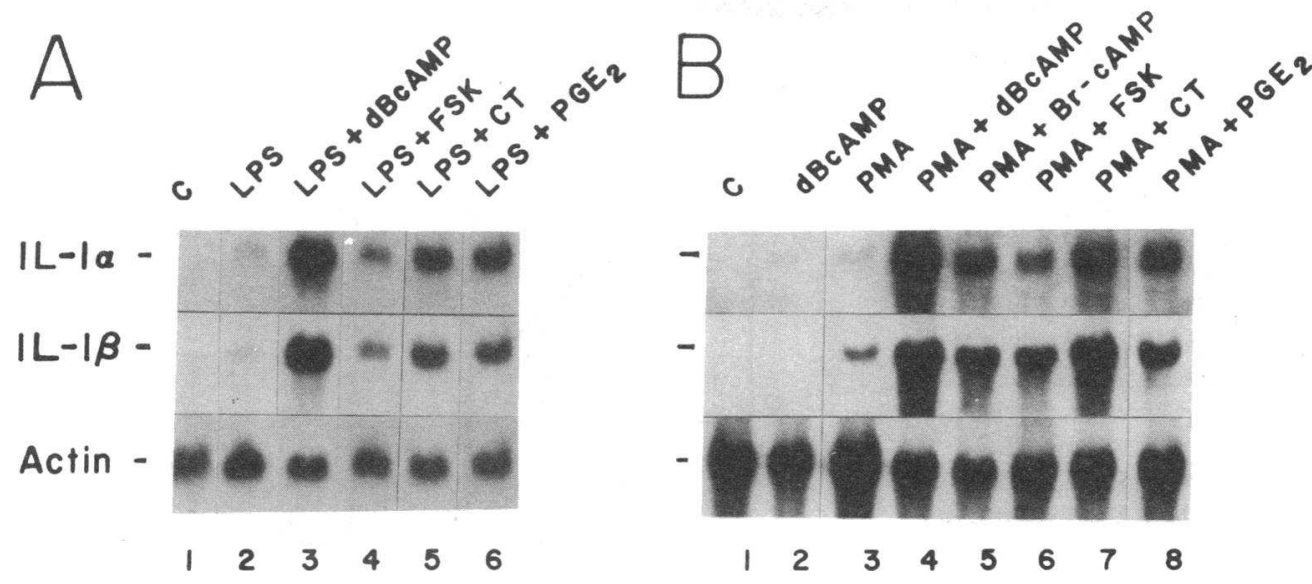

Figure 1. Effects of LPS, PMA, cAMP analogues, and adenylate cyclase stimulants on IL- $1 \alpha$ and IL- $1 \beta$ mRNA accumulation in ML-1 cells. Cells were resuspended at $10^{6} / \mathrm{ml}$ and stimulated with the indicated drugs for 16 h. RNA isolation, Northern blot analysis, and quantitation of band intensities were performed as in Methods. $(A) 5 \mu \mathrm{g}$ of poly $(A)^{+}$RNA, and $(B) 20 \mu \mathrm{g}$ of total RNA were loaded in each lane. The concentrations of drugs used were: $L P S, 1 \mu \mathrm{g} / \mathrm{ml}$; $P M A, 3 \mathrm{ng} / \mathrm{ml} ; d B c A M P, 0.5$ $\mathrm{mM}$; (FSK) forskolin, $25 \mu \mathrm{M}$;

(Br-cAMP) 8-bromo-cAMP, $1 \mathrm{mM} ;(C T)$ cholera toxin, $0.2 \mu \mathrm{g} / \mathrm{ml}$; and $P G E_{2}, 1 \mu \mathrm{M}$. The experiment is representative of three independent trials. The relative intensities for IL-1 mRNA were: In $A$, lanes $1-6$, IL-1 $\alpha: 0,1.0,38,3.2,11$, and 9.3; IL-1 $\beta$ : $0,1.0,48,3.6,15$, and 10 ; and in $B$, lanes $1-8$, IL- $1 \alpha: 0,0,1.0,42,11,3.2,22$, and 10 ; and IL-1 $\beta: 0,0,1.0,24,7.3,5.3,16$, and 5.0.

and IL- $1 \beta$-mRNA accumulation. PGF $_{2 \alpha}$, used as a control for its inability to elevate intracellular [cAMP], failed to synergize with LPS to further increase IL- $1 \alpha$ and IL- $1 \beta$ mRNA accumulation (not shown).

dBcAMP, 8-bromo-cAMP, forskolin, cholera toxin, and $\mathrm{PGE}_{2}$ also synergized with PMA in inducing IL-1 $\alpha$ and IL-1 $\beta$ mRNA accumulation (Fig. $1 B$ ). However, dBcAMP stimulated PMA-induced IL- $1 \beta$ mRNA accumulation by only 10 - to 20-fold (Fig. $1 B$, lane 4 ), compared to an approximately 50 fold stimulation of LPS induction. In addition, PMA was a much more potent inducer of IL-1 mRNA. The absolute magnitudes of IL- $1 \alpha$ and IL- $1 \beta$ mRNA, as estimated by comparing the exposure time of Northern blots, were one to two orders of magnitude higher in PMA-stimulated cells than in LPS-stimulated cells.

The response of the monocytic cell line U-937 to CAMP in IL- $1 \beta$-mRNA expression was similar to that of ML- 1 . In the presence of PMA, dBcAMP and forskolin increased IL- $1 \beta$ mRNA accumulation by nine- and fourfold, respectively, over that in U-937 cells stimulated with PMA alone (not shown).

Forskolin, cholera toxin, and $P G E_{2}$ elevated intracellular [ $c A M P$ ]. To demonstrate that increased IL- $1 \alpha$ - and IL- $1 \beta$ mRNA accumulation caused by forskolin, cholera toxin, and $\mathrm{PGE}_{2}$ in $\mathrm{ML}-1$ cells correlated with elevated intracellular [CAMP], the cAMP contents in cells stimulated with the drugs under IL-1 mRNA-induction conditions were measured (Fig. 2). Cells treated with PMA alone showed only a basal cAMP level. However, cells stimulated by the further addition of forskolin, cholera toxin, or $\mathrm{PGE}_{2}$ reproducibly increased their intracellular cAMP levels markedly. In cells stimulated with cholera toxin, the increase in CAMP level was slower than in those stimulated with forskolin or $\mathrm{PGE}_{2}$. The highest intracellular cAMP level of 40-70 pmol cAMP $/ 10^{7}$ cells was observed at 90 $\mathrm{min}$ for cholera toxin-stimulated cells, compared to $40 \mathrm{~min}$ for forskolin- or $\mathrm{PGE}_{2}$-stimulated cells.

Time course of $I L-1 \alpha$ and $I L-1 \beta$ mRNA accumulation in PMA- and PMA plus dBcAMP-stimulated cells. Before time course studies, the optimal PMA and dBcAMP concentrations for IL- $1 \alpha-$ mRNA expression were determined. IL- $1 \alpha$ and IL$1 \beta$ mRNA accumulation in ML-1 cells was highest when 3-10 $\mathrm{ng} / \mathrm{ml}$ of PMA was used. At $3 \mathrm{ng} / \mathrm{ml}$ PMA, dBcAMP showed maximal synergistic stimulation of IL-1 mRNA accumulation over a broad range between $25 \mu \mathrm{M}$ and $1 \mathrm{mM}$. The time course of IL- $1 \alpha$ and IL- $1 \beta$ mRNA accumulation in ML- 1 cells using optimal concentrations of PMA and dBcAMP is shown in Fig. 3. In ML- 1 cells stimulated with PMA alone, IL- $1 \alpha$ mRNA reached a plateau level between 4-8 $\mathrm{h}$ after stimulation. This level was maintained up to $28 \mathrm{~h}$. In cells stimulated with PMA plus dBcAMP, marked increases were observed in IL- $1 \alpha-$

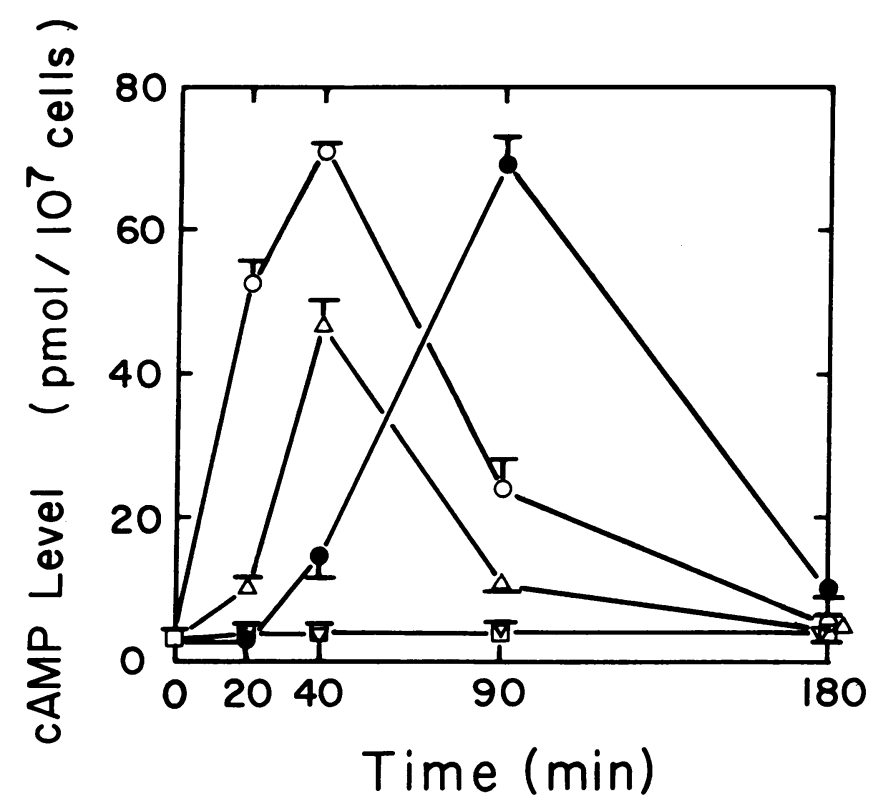

Figure 2. cAMP level of ML-1 cells incubated with PMA plus forskolin, cholera toxin, or $\mathrm{PGE}_{2}$. ML-1 cells were incubated with control medium ( $\square$ ), PMA ( $3 \mathrm{ng} / \mathrm{ml} ; \nabla)$, PMA plus $25 \mu$ M forskolin (o), PMA plus $1 \mu \mathrm{g} / \mathrm{ml}$ cholera toxin (๑), or PMA plus $10 \mu$ M PGE $_{2}(\Delta)$ for the indicated time periods and extracted with TCA as described in Methods. The cAMP content in each sample was measured in duplicate. The results are shown as mean $\pm \mathrm{SD}$ and are representative of two identical experiments. 


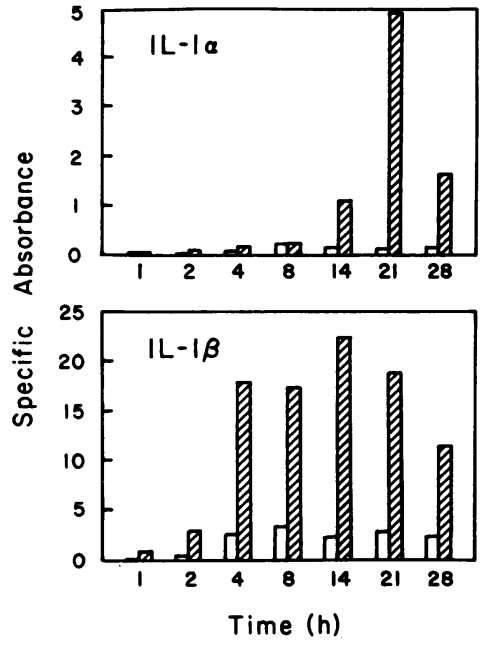

were normalized against that of $28 \mathrm{~S}$ rRNA, and were plotted as specific absorbance intensity. One of three similar experiments is shown.

mRNA accumulation, which reached peak levels $21 \mathrm{~h}$ after stimulation. This synergistic increase in IL-1 $\alpha$ mRNA level due to dBCAMP was up to 45-fold higher than that obtained by PMA stimulation alone. IL- $1 \beta$ mRNA expression in PMAtreated ML-1 cells appeared $2 \mathrm{~h}$ after stimulation and reached a plateau level within $4 \mathrm{~h}$. The synergistic action of $\mathrm{dBcAMP}$ and PMA caused IL- $1 \beta$ mRNA to appear after $1 \mathrm{~h}$, and reached peak level $4 \mathrm{~h}$ after drug addition. This peak IL-1 $\beta$ mRNA accumulation was maintained until $28 \mathrm{~h}$, and was up to 10 -fold higher than that in cells treated with PMA alone. Given the slight variabilities in IL-1 and 28S RNA measurements, these results were comparable to those in Fig. $1 B$, which gave synergistic dBcAMP stimulation at $16 \mathrm{~h}$ of about 40 - and 20 -fold for IL- $1 \alpha$ and IL- $1 \beta$ mRNA increases, respectively.

The time course of IL-1 $\beta$ mRNA accumulation in U-937 (not shown) was similar to that in ML-1, although the peak IL- $1 \beta$ mRNA level in cells treated with PMA plus dBcAMP occurred at $28 \mathrm{~h}$, and was about 20-fold higher than that in cells stimulated with PMA alone. Because both ML-1 and U-937 were similar in many respects regarding IL-1 mRNA accumulation, only ML-1 was studied further.

Half-lives of $I L-1 \alpha$ and $I L-1 \beta$ mRNAs in cells treated with $d B c A M P$. The increase in IL- $1 \alpha$ and IL- $1 \beta$ mRNA accumulation due to $\mathrm{dBcAMP}$ treatment in ML-1 cells could be a result of either increased mRNA stability or gene transcription rate. We examined the former possibility by performing mRNA decay studies. The half-lives of IL-1 $\alpha$ mRNA decaying in cells incubated in control medium, medium containing PMA alone, or medium containing both PMA and ABcAMP were similar, and were approximately $1-1.5 \mathrm{~h}$ (Fig. $4 \mathrm{~A}$ ). Similar experiments for IL- $1 \beta$ mRNA half-life determination were performed. To rule out the possibility that the presence of dBcAMP during preincubation caused irreversible phosphorylation or other biochemical events that might affect IL-1 mRNA half-lives during decay, cells were preincubated in medium containing PMA alone followed by IL- $1 \beta$ mRNA halflife determination in medium containing PMA alone or PMA
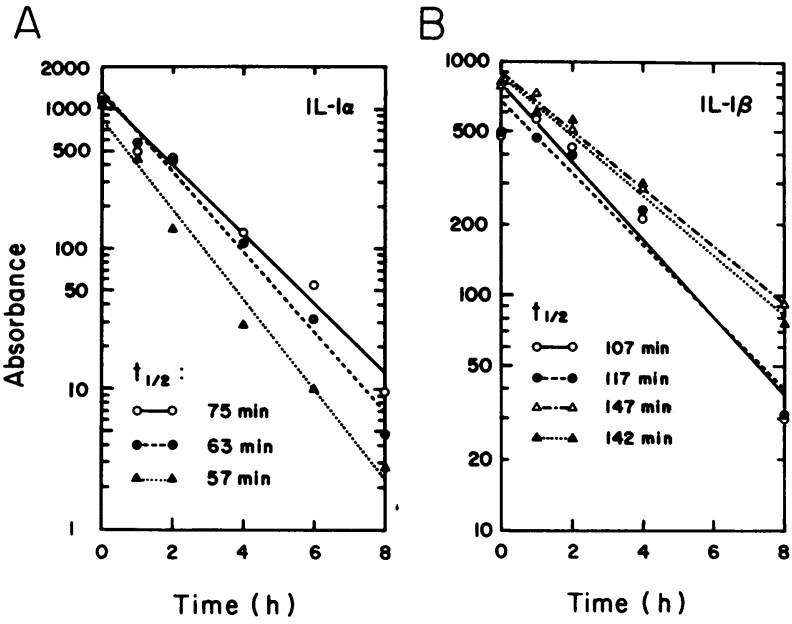

Figure 4. IL- $1 \alpha$ and IL-1 $\beta$ mRNA decay in ML-1 cells. $(A)$ ML-1 cells $\left(10^{6} / \mathrm{ml}\right)$ were stimulated with $3 \mathrm{ng} / \mathrm{ml}$ PMA and $0.5 \mathrm{mM} \mathrm{dBcAMP}$ for $16 \mathrm{~h}$. The cells were harvested, washed, and resuspended at 2 $\times 10^{6} / \mathrm{ml}$ in actinomycin D-containing medium with no addition (o, $r=0.990), \operatorname{PMA}(\bullet, r=0.994)$, or PMA plus $\operatorname{dBcAMP}(\Delta, r=0.992)$ for the indicated time periods. Northern blot analysis and IL-1 mRNA quantitation were performed as described in Methods. A semilogarithmic plot of IL-1 $\alpha$ mRNA absorbance is plotted versus time. The half-lives of the IL- $1 \alpha$ mRNA in cells with various treatments are indicated. $(B)$ ML-1 cells were preincubated at $2 \times 10^{6} / \mathrm{ml}$ in medium containing $3 \mathrm{ng} / \mathrm{ml}$ PMA [o, $(r=0.971) ; \bullet,(r=0.969)]$ or $3 \mathrm{ng} / \mathrm{ml}$ PMA and $0.5 \mathrm{mM} \mathrm{dBcAMP}[\Delta,(r=0.999) ; \Delta,(r=0.991)]$ for $8 \mathrm{~h}$. IL-1 $\beta \mathrm{mRNA}$ decay was measured in cells treated with actinomycin D-containing medium with $3 \mathrm{ng} / \mathrm{ml} \operatorname{PMA}(0, \Delta)$ or $3 \mathrm{ng} / \mathrm{ml}$ PMA plus $0.5 \mathrm{mM}$ dBcAMP $(\bullet, \Delta)$ as in $A$. The curves were fitted by first order regression using the program SigmaPlot. The correlation coefficient ( $r$ value) of each curve is given behind each of the symbols.

plus dBcAMP (Fig. 4 B). Irrespective of whether ABcAMP was present during the preincubation or decay periods, IL- $1 \beta$ mRNA exhibited similar half-lives of 2-2.5 h. These results indicated that the increased IL- $1 \alpha$ and IL- $1 \beta$ mRNA accumulation due to dBcAMP was not a consequence of increased IL-1 mRNA stability.

Effects of elevated intracellular CAMP on $I L-1 \alpha$ and $I L-1 \beta$ gene transcription rates. Unstimulated ML-1 cells showed no detectable IL- $1 \alpha$ and IL- $1 \beta$ gene transcription activities. Low IL- $1 \beta$ gene transcription activities were observed in cells treated with PMA for 6,14 , and $16 \mathrm{~h}$ (Fig. $5 A ; 14 \mathrm{~h}$ not shown). Transcription of the IL- $1 \alpha$ gene in these cells was observed only during the later time points. At the three specified time points in cells treated with PMA plus dBcAMP, however, the transcription rate was a 10 - to 15 -fold higher than in cells stimulated with PMA alone. For IL-1 $\alpha$ transcription, the increase due to dBcAMP was only two- to threefold at $6 \mathrm{~h}$, but rose to 18-fold at the later time points.

The observed difference in the IL- $1 \alpha$ and IL- $1 \beta$ transcription kinetics was further analyzed (Fig. $5 C$ ). Between 6 and 16 $h$, there was a small increase in IL- $1 \alpha$ and IL-1 $\beta$ transcription rates in cells stimulated with PMA alone (not shown). In cells treated with PMA plus dBcAMP, however, IL-1 $\beta$ transcription activities increased steadily over time, reached peak levels at 10 $\mathrm{h}$, and slowly decreased to $50 \%$ peak activity at $24 \mathrm{~h}$. The kinetics of IL- $1 \alpha$ transcription rates in these cells were different. 


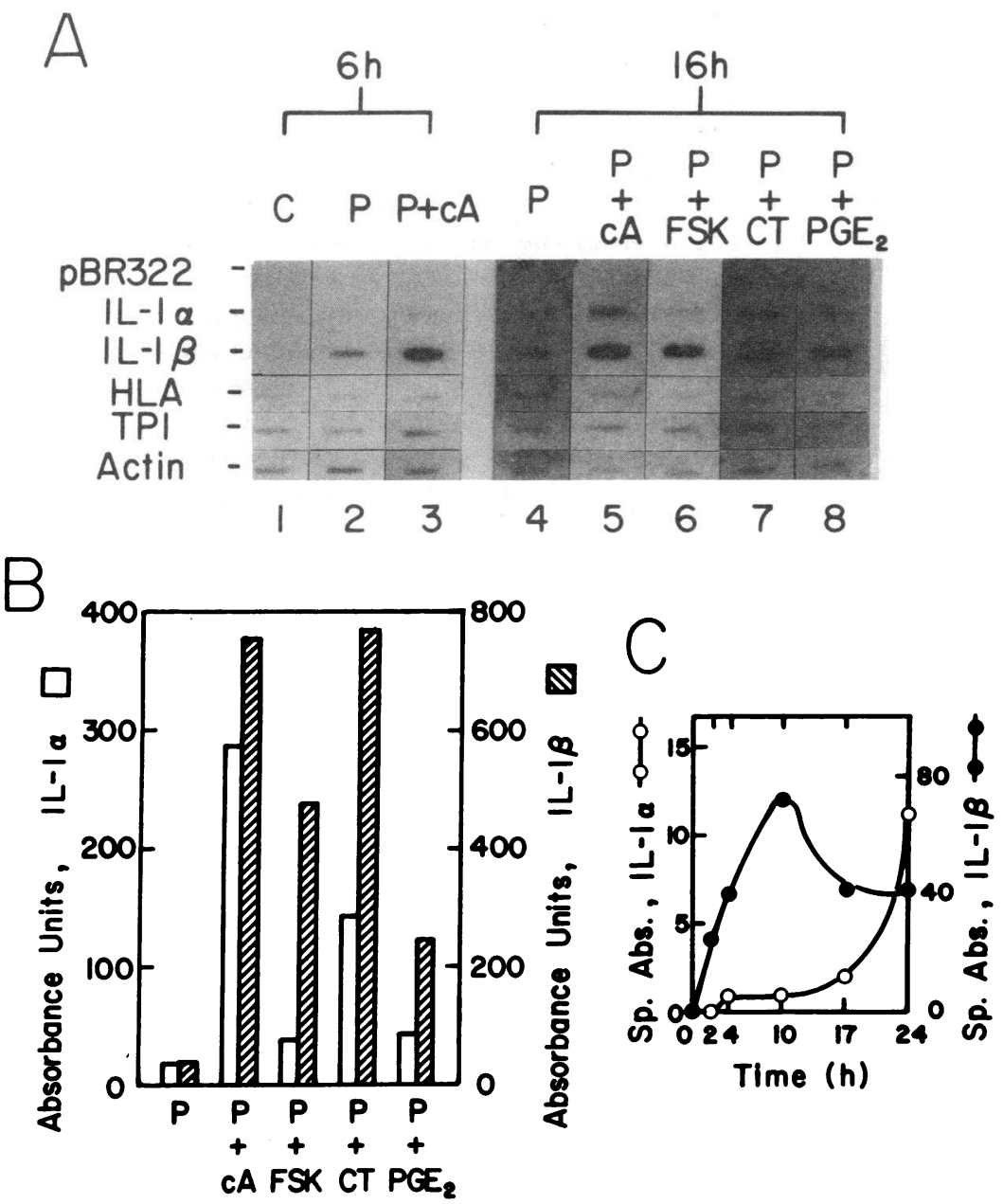

Figure 5. Nuclear run-on assays of IL-1 transcription rates in ML-1 cells stimulated with PMA plus dBcAMP or adenylate cyclase stimulants. Nuclear run-on assays were performed as described in Methods. Nuclei were harvested after stimulation for the indicated time periods and assayed. In $A$, the concentration of drugs used were: $(P)$ PMA, 3 $\mathrm{ng} / \mathrm{ml} ;(C A)$ dBcAMP, $0.5 \mathrm{mM}$; (FSK) forskolin, 25 $\mu \mathrm{M} ;(C T)$ cholera toxin, $1 \mu \mathrm{g} / \mathrm{ml}$; and $\mathrm{PGE}_{2}, 10$ $\mu \mathrm{M}$. The absorbance of IL-1 $\alpha$ and IL- $1 \beta$ run-on transcripts in $A$, lanes 4-8, were plotted in $B$. The time course of IL- $1 \alpha$ and IL- $1 \beta$ transcription rates in PMA $(3 \mathrm{ng} / \mathrm{ml})$ plus cAMP-treated $(0.5 \mathrm{mM})$ ML-1 cells were normalized against that of triose-phosphate isomerase, a constitutively expressed gene, and plotted in $C$. Three similar experiments were performed for $A$ and two for $C$.
A low but readily detectable activity was observed at $4 \mathrm{~h}$. This low activity was maintained until $17 \mathrm{~h}$, and rose sharply between 17 and $24 \mathrm{~h}$. Based on the band intensities in the run-on experiments, IL- $1 \beta$ gene transcription rate in PMA plus dBcAMP-treated cells was estimated to be 50 - to 80 -fold higher than that of IL- $1 \alpha$ gene between 4 and $17 \mathrm{~h}$. But at $24 \mathrm{~h}$, IL-1 $\beta$ transcription rate was only about sixfold higher.

The effects of forskolin, cholera toxin, and $\mathrm{PGE}_{2}$ on IL- $1 \alpha$ and IL- $1 \beta$ transcription rates were also examined (Fig. 5, $A$ and $B)$. The constitutively transcribed genes HLA, triose-phosphate isomerase, and $\beta$-actin showed similar transcriptional activities in all samples (Fig. $5 \mathrm{~A}$ ). At $16 \mathrm{~h}$, PMA plus forskolin or $\mathrm{PGE}_{2}$ caused three- to fourfold higher IL- $1 \alpha$, and four- to fivefold higher IL-1 $\beta$ transcription rates than PMA alone (Fig. $5 B$ ). dBcAMP and cholera toxin caused much higher transcriptional activities; dBcAMP acted synergistically with PMA to cause 20 -fold higher IL- $1 \alpha$ and sixfold higher IL- $1 \beta$ transcription rates, and cholera toxin with PMA induced 10- and 7-fold higher IL- $1 \alpha$ and IL- $1 \beta$ transcription rates, respectively, compared to PMA alone.

dBCAMP and adenylate cyclase stimulants synergized with $L P S$ to increase monocyte IL-1 $\alpha$ and IL-1 $\mathrm{mRNA}$ accumulation. Peripheral blood monocytes cultured without added stimuli did not express detectable IL- $1 \alpha$ or IL-1 $\beta$ mRNA. Because monocytes show reduced capacity to synthesize IL-1 upon cul- ture in vitro, emphasis was placed on examining IL-1 mRNA expression in freshly isolated monocytes or monocytes cultured overnight. LPS at $0.1-1 \mu \mathrm{g} / \mathrm{ml}$ maximally stimulated these cells to express IL- $1 \alpha$ and IL- $1 \beta$ mRNA that peaked 2-4 $h$ after stimulation. Time course with LPS plus $\mathrm{ABCAMP}$ indicated that dBcAMP increased the maximum but did not change the peak time. Furthermore, the elevated mRNA levels were sustained longer. $\mathrm{dBcAMP}, \mathrm{PGE}_{2}$, forskolin, and cholera toxin increased the accumulation of IL- $1 \alpha$ mRNA by 2-, 4-, 5-, and 20 -fold, and IL-1 $\beta$ mRNA by 7-, 5-, 3-, and 13-fold, respectively (Fig. 6). This increase due to cAMP elevation is in most cases lower than that in the cell lines examined. However, because these fresh monocytes secrete endogenous prostaglandins upon LPS stimulation, the possibility of autostimulation of IL-1 mRNA accumulation by endogenously synthesized prostaglandins was examined. Indomethacin, which blocks the cyclooxygenase pathway (28), inhibited IL- $\alpha$ and IL- $1 \beta$ mRNA level in LPS-stimulated monocytes by $40-60 \%$ (Fig. 6, lane 3). Thus, about half of the increase in IL-1 mRNA accumulation in these monocytes was due to stimulation by endogenously synthesized prostaglandins. Nuclear run-on experiments showed that indomethacin decreased LPS-stimulated IL- $1 \beta$ transcription rate by about $50 \%$, while $\mathrm{dBcAMP}$ and cholera toxin increased that rate by about two- and threefold, respectively. 


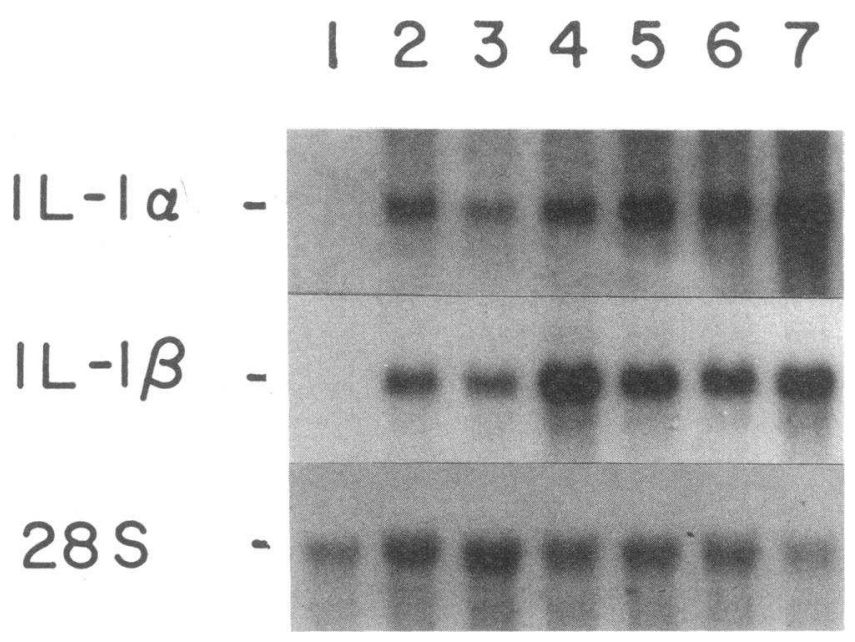

Figure 6. Expression of IL-1 mRNA in fresh monocytes stimulated with LPS plus drugs that modulate intracellular [CAMP]. Freshly isolated monocytes were plated in Teflon dishes at $2 \times 10^{6}$ cells $/ \mathrm{ml}(15$ $\times 10^{6}$ cells $/$ sample) and stimulated for $4 \mathrm{~h}$ with $100 \mathrm{ng} / \mathrm{ml} \mathrm{LPS} \mathrm{(lane}$ 2), LPS plus $1 \mu \mathrm{M}$ indomethacin (lane 3), LPS plus $250 \mu \mathrm{M} \mathrm{dBcAMP}$ (lane 4), LPS plus $10 \mu \mathrm{M}$ PGE $_{2}$ (lane 5), LPS plus $25 \mu \mathrm{M}$ forskolin (lane 6), or LPS plus $0.5 \mu \mathrm{g} / \mathrm{ml}$ cholera toxin (lane 7). Lane 1 contains RNA from cells receiving no stimulant. Total RNA was isolated, fractionated on $1.4 \%$ agarose gel, and transferred to nylon membranes. IL- $1 \alpha, \mathrm{IL}-1 \beta$, and $28 \mathrm{~S}$ RNA were probed as described in Methods. The relative intensities of IL- $1 \alpha$ and IL- $1 \beta$ bands in lanes 1-7 after normalization against 28S RNA were: $(I L-1 \alpha) 0,1.0,0.44$, 2.0, 4.2, 4.7, and 20; and $(I L-1 \beta) 0,1.0,0.59,7.1,4.5,2.8$, and 13 . The results are representative of three experiments.

Production of $I L-1 \alpha$ and $I L-1 \beta$ by $M L-1$ cells and monocytes. Cell-associated IL- $1 \beta$ was the major IL-1 form produced by ML-1 cells stimulated with PMA for $12-24 \mathrm{~h}$. It occurred as a series of fragments ranging in apparent molecular weight from 33 to $14 \mathrm{kD}$ (Fig. $7 A$ ). Secreted IL-1 $\beta$, composed of a major 33-kD band and minor bands at 17-19 kD (Fig. $7 \mathrm{~B}$ ), was only $\sim 10-20 \%$ of the amount of cell-associated IL- $1 \beta$.
Cell-associated IL- $1 \alpha$ at 31 and $17 \mathrm{kD}$ was synthesized in much lower amounts than IL- $1 \beta$ (Fig. $7 A$ ) and the secreted IL- $1 \alpha$ was barely detectable at $24 \mathrm{~h}$. dBcAMP, at a concentration that increased IL- $1 \beta$ mRNA accumulation by 10 - to 20 -fold, increased cell-associated IL- $1 \beta$ by only about twofold, and did not appreciably increase the amount of secreted IL- $1 \beta$ (Fig. 7 $B$ ). The cell-associated IL- $1 \beta$ synthesis rate due to $\mathrm{dBcAMP}$, over a time course of 3-24 h, was only double that in cells treated with PMA alone (Fig. 8), and did not correlate with the 10 -fold increase in IL-1 $\beta$ mRNA level over this same period (Fig. 3). There was little detectable increase of cell-associated IL-1 $\alpha$ synthesis in PMA plus dBcAMP-treated cells over that in cells treated with PMA alone (Fig. $7 A$ ), although the IL-1 $\alpha$ mRNA level in the former cells was up to 50 -fold higher (Fig. 3).

Freshly isolated monocytes did not synthesize IL-1. When stimulated with LPS, monocytes synthesized IL- $1 \alpha$ and IL- $1 \beta$ species similar in molecular size to those synthesized by ML-1 cells, though the proportion of various IL-1 species differed between the two cell types (Fig. 9). dBcAMP, $\mathrm{PGE}_{2}$, forskolin, and cholera toxin increased cell-associated IL- $1 \alpha$ and IL- $1 \beta$, and secreted IL- $1 \beta$ about twofold. Indomethacin, which inhibited LPS-induced mRNA increase, decreased LPS-induced IL- 1 synthesis by about $50 \%$. Secreted IL- $1 \alpha$ in monocytes was a minor component synthesized by monocytes.

\section{Discussion}

cAMP is generally thought to inhibit IL-1 synthesis posttranscriptionally (1). The evidence for this concept is based mostly upon the work on mouse peritoneal macrophages $(19,28,29)$. However, in human monocytes stimulated with LPS, previous reports $(17,18)$, as well as our present results, show that cAMP analogs and other agents that elevate intracellular cAMP increase IL-1 mRNA accumulation and IL-1 production severalfold. However, when stimulated by another agent, toxic shock supernatant, monocytes synthesized slightly less IL-1 when intracellular cAMP level was increased by $\mathrm{PGE}_{2}$ (7). Thus, the

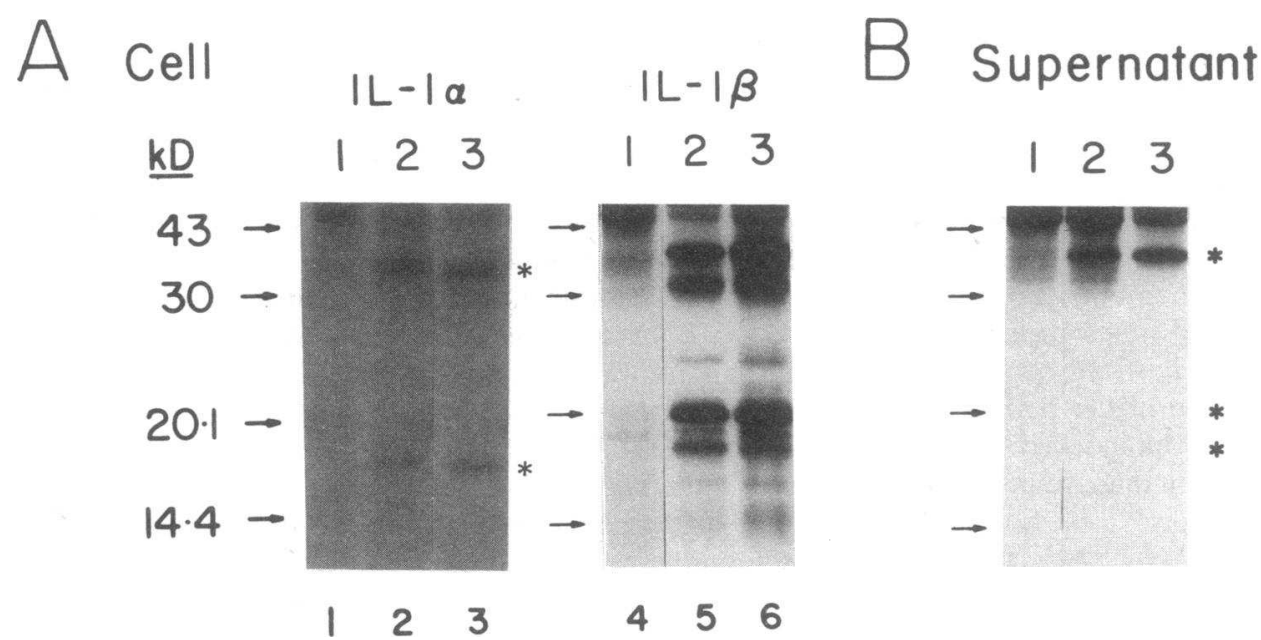

Figure 7. IL-1 production by ML-1 cells. ML- 1 cells $\left(10^{6}\right.$ cells $/ \mathrm{ml} ; 4$ $\mathrm{ml} / \mathrm{sample}$ ) were plated in Met-free RPMI 1640 with $10 \%$ dialysed FCS, $\left.50 \mu \mathrm{Ci} / \mathrm{ml} \mathrm{[}{ }^{35} \mathrm{~S}\right] \mathrm{Met}, 2 \mathrm{mM}$ glutamine, $50 \mu \mathrm{g} / \mathrm{ml}$ streptomycin, 50 $\mathrm{U} / \mathrm{ml}$ penicillin, and stimulated for $24 \mathrm{~h}$ with $3 \mathrm{ng} / \mathrm{ml}$ PMA (lane 2, top), $3 \mathrm{ng} / \mathrm{ml}$ PMA plus $0.5 \mathrm{mM}$ dBcAMP (lane 3, top), or with no stimulation (lane 1, top). Immunoprecipitation of IL- $1 \alpha$ and IL- $1 \beta$ was performed as described in Methods. $A$ shows immunoprecipitation of IL- $1 \alpha$ and IL- $1 \beta$ from cell pellets and $B$ shows immunoprecipitation of IL- $1 \beta$ from cell supernatants. * in $A$ shows IL-1 $\alpha$ bands and in $B$ shows IL- $1 \beta$ bands. The mature 17$20-\mathrm{kD}$ IL- $1 \beta$ bands in $B$ are distinctly visible in longer exposures. Arrows on the left show the position of molecular weight markers. One of two experiments is shown. 


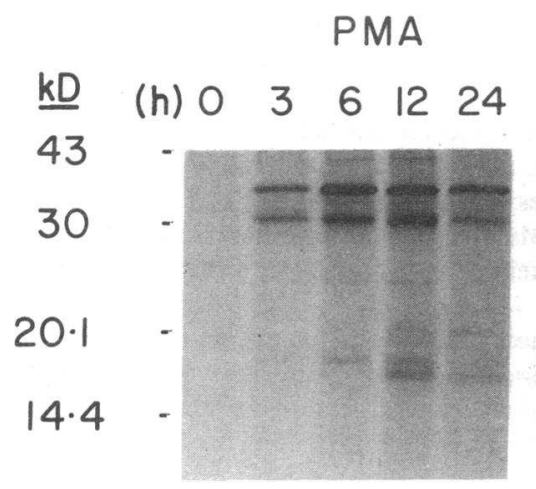

12345
$\mathrm{PMA}+\mathrm{dBCAMP}$
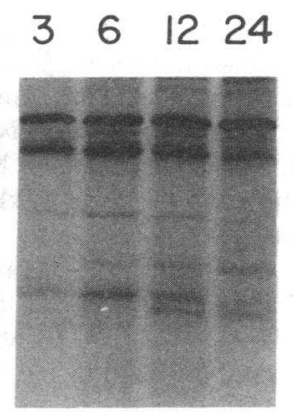

$\begin{array}{llll}6 & 7 & 8 & 9\end{array}$
$A$

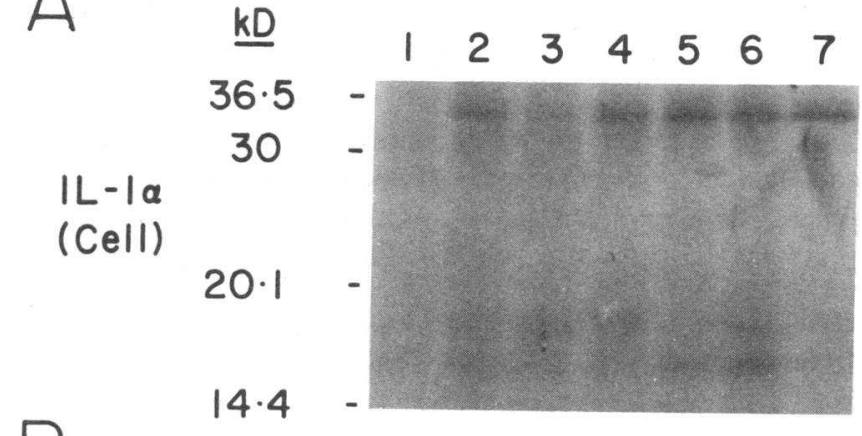

B

Figure 8. Time course of cell-associated IL-1 $\beta$ synthesis in ML-1 cells. Cells were labeled as in Fig. 7 in the presence of $3 \mathrm{ng} / \mathrm{ml} \mathrm{PMA}$ (lanes 2-5) or $3 \mathrm{ng} / \mathrm{ml}$ PMA plus $0.5 \mathrm{mM}$ dBcAMP (lanes 6-9). At the indicated time points cells were collected and lysed. IL- $1 \beta$ was immunoprecipitated from the NP-40 lysate as described in Methods. One of two similar experiments is shown.

effects of CAMP on IL-1 synthesis is cell type- and stimulant dependent.

cAMP analogues and adenylate cyclase stimulants markedly increased the transcription rate and accumulation of IL-1 mRNA in several monocytic and myeloid cell lines stimulated by LPS or PMA. However, only a twofold increase in IL-1 synthesis was observed. This observation of a small increase in IL-1 cytokine synthesis, despite mRNA accumulation increases of up to 50-fold for IL- $1 \alpha$ and 10- to 20 -fold for IL-1 $\beta$, indicates that IL-1 synthesis is under stringent translational control. Similar findings observed in mouse macrophages also showed that CAMP stimulation of marked IL-1 mRNA accumulation increases was followed by only a small increase in IL-1 cytokine production (30). This small overall increase in IL-1 production may be due to increased IL-1 degradation rate concomitant with increased IL-1 synthesis rate or, alternatively, due to IL-1 translational control. If the former were true, the degradation rate for IL-1 would have to be increased by $10-$ to 50 -fold. This increase seems to be extraordinarily high unless an IL-1-specific degradation mechanism occurs. The latter possibility of translational regulation by some cAMP-dependent phosphorylation event seems more likely. The synthesis of TNF, another major monocyte product, is also regulated translationally (10). The regulatory sequence resides in the $3^{\prime}$ untranslated region of TNF $m$ RNA. IL-1 mRNA shares a number of sequence motifs with TNF mRNA in this 3'-untranslated region (31). Whether similar mechanisms regulate IL-1 and TNF synthesis will have to be empirically determined.

The synthesis of IL-1 by monocytes is stimulated by LPS and cytokines such as TNF and GM-CSF, and by IL-1 itself ( 1 , 9, 14-16). The synergistic stimulation of IL-1 mRNA accumulation by CAMP and adenylate cyclase stimulants suggests that PGE may be important in regulating IL-1 synthesis in vivo. $\mathrm{PGE}_{1}$ and $\mathrm{PGE}_{2}$ may augment the stimulation of IL-1 transcription by cytokines and other monocyte stimulants such as immune complexes. In addition, because monocytes produce large amounts of PGs (32), PGE may assume an autocrine role in stimulating the PG-producing monocytes to transcribe IL-1 mRNA. Because PGs are short lived in vivo (1), the PG-me-

.

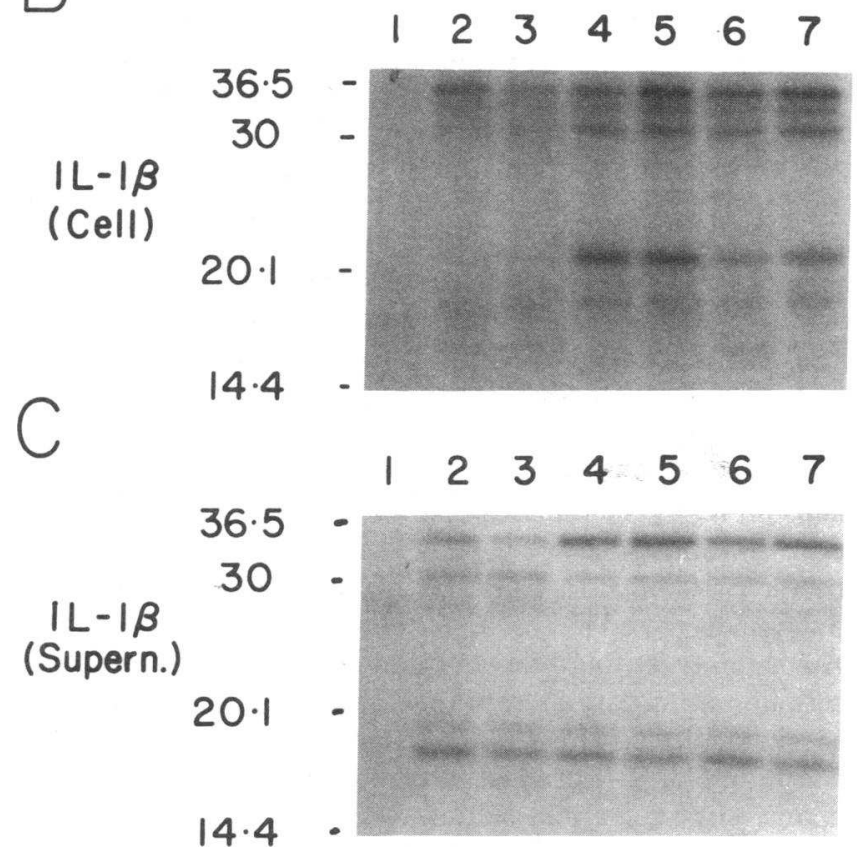

Figure 9. IL-1 synthesis by peripheral blood monocytes. Freshly isolated monocytes were labeled in labeling medium that has passed through a polymyxin B-agarose column. Cells $\left(3 \times 10^{6} / \mathrm{ml}, 4\right.$ $\mathrm{ml} / \mathrm{sample}$ ) were labeled for $24 \mathrm{~h}$ with no stimulation (lane 1 ), or with $100 \mathrm{ng} / \mathrm{ml}$ LPS (lane 2), LPS plus $1 \mu \mathrm{M}$ indomethacin (lane 3), LPS plus $250 \mu \mathrm{M}$ dBcAMP (lane 4), LPS plus $10 \mu \mathrm{M}$ PGE $_{2}$ (lane 5), LPS plus $25 \mu \mathrm{M}$ forskolin (lane 6), or LPS plus $0.5 \mu \mathrm{g} / \mathrm{ml}$ cholera toxin (lane 7). Cell pellets $(A$ and $B)$ and supernatants $(C)$ were used in the immunoprecipitation of IL-1 $\alpha(A)$ and IL-1 $\beta(B$ and $C)$ as described in Methods. IL- $\alpha$ bands in cell supernatants were not as clearly distinguishable and are not shown. The results are representative of three experiments.

diated inhibition of IL-1 translation may be rapidly reversed. Given the slow degradation rate of IL- $1 \beta$ mRNA $\left(t_{1 / 2}\right.$ of $\sim 2 \mathrm{~h}$, Fig. 4), the net result of PGE stimulation may be an enhancement of IL-1 synthesis due to a transient augmentation of IL-1 mRNA transcription.

The stimulation of IL-1 mRNA transcription and cytokine synthesis by agents that activate adenylate cyclase or mimic intracellular cAMP is consistent with the postulated mode of action of IL-1 and GM-CSF. Both growth factors stimulate various cell types to produce IL-1, and this stimulation correlates with their ability to elevate intracellular cAMP (12-16). However, cAMP elevation alone failed to stimulate IL-1 gene 
transcription. Because IL-1 or GM-CSF alone can stimulate IL-1 synthesis, they must induce the formation of other costimulating signals such as protein kinase $C$ activators to adequately activate IL-1 transcription. Indeed, IL-1 has been shown to stimulate the production of intracellular diacylglycerol, an endogenous protein kinase $\mathrm{C}$ activator, from phosphatidylcholine (33). These two IL-1-induced second messengers, diacylglycerol and cAMP, would be sufficient to activate the IL-1 gene.

Despite using a few different approaches, including stimulation with reversibly bound phorbol esters (Sung, S. J., and J. A. Walters, unpublished results), we failed to show that PMA or dBcAMP appreciably increased IL- $1 \alpha$ and IL- $1 \beta$ half-lives (Fig. 4). However, PMA alone and PMA plus dBcAMP increased IL- $1 \alpha$ mRNA accumulation considerably (Fig. 3 ) before the transcription rate of IL- $1 \alpha$ showed any detectable increase (Fig. 5, $A$ and $C$ ). This increase in accumulation could still be due to stabilization of IL- $1 \alpha$ mRNA by PMA or dBcAMP because to measure the rate of mRNA decay of inducible mRNAs such as IL-1, a stimulant such as PMA must first be used to elevate the mRNA level to the extent that the decay rate can be conveniently measured. However, this stimulant may also cause mRNA stabilization by stimulating reactions that may not be readily reversible, and thus the stabilization is not detectable by present methods.

The effects of cAMP analogues and adenylate cyclase stimulants on IL-1 gene transcription is markedly different between primary monocytes and myelomonocytic cell lines. It has also been reported that IL-1 mRNA transcription and protein production decreased in human monocytes cultured in vitro (34). A possibility for this difference may be that the profiles of transcription factors are altered in cell lines and in monocytes upon in vitro culture. This change will affect the time course and magnitude of IL-1 gene transcription and its transcription responsiveness to various stimuli.

How elevation of intracellular cAMP increases IL-1 gene transcription rates is unclear. Evidence in our laboratory showed that A23187 had no synergistic effects on PMA in the stimulation of IL-1 mRNA expression. Thus, cAMP does not appear to increase IL-1 gene transcription by affecting cytosolic-free $\mathrm{Ca}^{2+}$ levels. A direct activation of the cAMP-responsive element-binding protein to bind to a cAMP-responsive element in the promoter region of the IL-1 genes (11) seems unlikely because we were unable to identify the cAMP-responsive element motif in that region of the IL-1 genes. The delayed effects of CAMP in enhancing PMA-stimulated IL-1 expression suggest a secondary effect for cAMP. cAMP may activate other transcription factors that can activate IL-1 genes. Possible DNA-binding proteins involved in this activation are c-Fos, Jun B, and NFKB. c-Fos and Jun B synthesis $(35,36)$ and NF $\kappa$ B-binding activities (37) are stimulated by cAMP. c-Fos and Jun $B$ form a heterodimer that activates gene transcription by binding to the ubiquitous AP- 1 binding site. $N F \kappa$, on the other hand, binds to a $\kappa$-enhancing element, and has been shown to be important in enhancing the transcription of immunoglobulin, cytokines, MHC class I, and IL-2R genes (38). Both the AP-1- and the NF $\kappa$ B-like binding elements are present in the IL- $1 \alpha$ and IL- $1 \beta$ promoter regions. They serve as important candidates for the cAMP activation targets in IL- $1 \alpha$ and IL- $1 \beta$ gene transcription.

\section{Acknowledgements}

We thank Drs. Shu Man Fu, Jeffrey Gimble, Kathleen McCoy, and Peck-Sun Lin for suggestions and for critically reviewing the manuscript; Drs. David Cosman, Marc Kirschner, and Sherman Weissman for providing cDNA probes; Dr. R. Chizzonite for providing us with the anti-IL-1 antibodies; Ms. Jackie Moore for preparing the manuscript; and Dr. Ross Mikkelsen for assistance with the Loats Digital Video Imaging System.

This work was supported in part by an Oklahoma Center for the Advancement of Science and Technology grant (HR9-045), while the authors were at the Oklahoma Medical Research Foundation, Oklahoma City, OK.

\section{References}

1. Dinarello, C. A. 1989. Interleukin-1 and its biologically related cytokines. Adv. Immunol. 44:153-205.

2. Sims, J. E., C. J. March, D. Cosman, M. B. Widmer, H. R. MacDonald, C. J. McMahan, C. E. Grubin, J. M. Wignall, J. L. Jackson, S. M. Call, D. Friend, A. R. Alpert, S. Gillis, D. L. Urdal, and S. K. Dower. 1988. cDNA expression cloning of the IL-1 receptor, a member of the immunoglobulin superfamily. Science (Wash. DC). 241:585-589.

3. Bensimon, C., N. Wakasugi, Y. Tagaya, K. Takakura, J. Yodoi, T. Tursz, and $H$. Wakasugi. 1989. Two distinct affinity binding sites for IL-1 on human cell lines. J. Immunol. 143:1168-1174.

4. March, C. J., B. Moseley, A. Larsen, D. P. Cerretti, G. Braedt, V. Price, S Gillis, C. S. Henney, S. R. Kronheim, K. Grabstein, P. J. Conlon, T. P. Hopp, and D. Cosman. 1985. Cloning, sequence and expression of two distinct human interleukin-1 complementary DNAs. Nature (Lond.). 315:641-647.

5. Beuscher, H. U., C. Günther, and M. Röllinghoff. 1990 . IL-1 $\beta$ is secreted by activated murine macrophages as biologically inactive precursor. J. Immunol. 144:2179-2183.

6. Kostura, M. J., M. J. Tocci, G. Limjuco, J. Chin, P. Cameron, A. G. Hillman, N. A. Chartrain, and J. A. Schmidt. 1989. Identification of a monocyte specific pre-interleukin $1 \beta$ convertase activity. Proc. Natl. Acad. Sci. USA. 86:5227-5231.

7. Knudsen, P. J., C. A. Dinarello, and T. B. Strom. 1986. Prostaglandins posttranscriptionally inhibit monocyte expression of interleukin 1 activity by increasing intracellular cyclic adenosine monophosphate. J. Immunol. 137:3189-3194.

8. Kern, J. A., R. J. Lamb, J. C. Reed, R. P. Daniele, and P. C. Nowell. 1988. Dexamethasone inhibition of interleukin 1 beta production by human monocytes. J. Clin. Invest. 81:237-244.

9. Elias, J. A., M. M. Reynolds, R. M. Kotloff, and J. A. Kern. 1989. Fibroblast interleukin $1 \beta$ : synergistic stimulation by recombinant interleukin 1 and tumor necrosis factor and posttranscriptional regulation. Proc. Natl. Acad. Sci. USA. 86:6171-6175.

10. Han, J., T. Brown, and B. Beutler. 1990. Endotoxin-responsive sequences control cachectin/tumor necrosis factor biosynthesis at the translational level. $J$. Exp. Med. 171:465-475.

11. Roesler, W. J., G. R. Vandenbark, and R. W. Hanson. 1988. Cyclic AMP and the induction of enkaryotic gene transcription. J. Biol. Chem. 263:90639066.

12. Shirakawa, F., U. Yamashita, M. Chedid, and S. B. Mizel. 1988. Cyclic AMP-an intracellular second messenger for interleukin 1. Proc. Natl. Acad. Sci. USA. 85:8201-8205.

13. Coleman, D. L., J. Liu, and A. H. Bartiss. 1989. Recombinant granulocyte-macrophage colony-stimulating factor increases adenylate cyclase activity in murine peritoneal macrophages. J. Immunol. 143:4134-4140.

14. Dinarello, C. A., T. Ikejima, S. J. C. Warner, S. F. Orencole, G. Lonnemann, J. G. Cannon, and P. Libby. 1987. Interleukin 1 induces interleukin 1: I. Induction of circulating interleukin 1 in rabbits in vivo and in human mononuclear cells in vitro. J. Immunol. 139:1902-1910.

15. Warner, S. J. C., K. R. Auger, and P. Libby. 1987. Interleukin 1 induces interleukin 1. II. Recombinant human interleukin 1 induces interleukin 1 production by adult human vascular endothelial cells. J. Immunol. 139:1911-1917.

16. Lindemann, A., D. Riedel, W. Oster, S. C. Meuer, D. Blohm, R. H Mertelsmann, and F. Herrmann. 1988. Granulocyte/macrophage colony-stimulating factor induces interleukin 1 production by human polymorphonuclear neutrophils. J. Immunol. 140:837-839.

17. Kassis, S., J. C. Lee, and N. Hanna. 1989. Effects of prostaglandins and cAMP levels on monocyte IL-1 production. Agents Actions. 27:274-276.

18. Scales, W. E., S. W. Chensue, I. Otterness, and S. L. Kunkel. 1989. Regulation of monokine gene expression: prostaglandin $E_{2}$ suppresses tumor necrosis 
factor but not interleukin-1 $\alpha$ or $\beta$-mRNA and cell-associated bioactivity. J. Leukocyte Biol. 45:416-421.

19. Brandwein, S. R. 1986. Regulation of interleukin 1 production by mouse peritoneal macrophages. Effects of arachidonic acid metabolites, cyclic nucleotides and interferons. J. Biol. Chem. 261:8624-8632.

20. Eisenberg, S. P., R. J. Evans, W. P. Arend, E. Verderber, M. T. Brewer, C. H. Hannum, and R. C. Thompson. 1990. Primary structure and functional expression from complementary DNA of a human interleukin-1 receptor antagonist. Nature (Lond.). 343:341-346.

21. Sung, S.-S. J., J. M. Bjorndahl, C. Y. Wang, H. T. Kao, and S. M. Fu. 1988. Production of tumor necrosis factor/cachectin by human $T$ cell lines and peripheral blood $\mathrm{T}$ lymphocytes stimulated by phorbol myristate acetate and anti-CD3 antibody. J. Exp. Med. 167:937-953.

22. Sung, S.-S. J., and J. A. Walters. 1989. Identification and characterization of a hamster monoclonal antibody anti-2.28 directed against a 70-kilodalton activation antigen on human monocytes. J. Immunol. 142:1903-1908.

23. Sambrook, J., E. F. Fritsch, and T. Maniatis. 1989. Molecular Cloning: A Laboratory Manual. 2nd ed. Cold Spring Harbor Laboratory Press, Cold Spring Harbor, NY. 1546 pp.

24. Sung, S.-S. J., L. K. L. Jung, J. A. Walters, E. W. B. Jeffes, III, G. A. Granger, and S. M. Fu. 1989. Production of lymphotoxin by isolated human tonsillar B lymphocytes and B lymphocyte cell lines. J. Clin. Invest. 84:236-243.

25. Barbu, V., and F. Dautry. 1989. Northern blot normalization with a $28 S$ rRNA oligonucleotide probe. Nucleic Acid Res. 17:7115.

26. Nevins, J. R. 1987. Isolation and analysis of nuclear RNA. Methods Enzymol. 152:234-241.

27. Okayama, H., and P. Berg. 1982. High-efficiency cloning of full-length cDNA. Mol. Cell. Biol. 2:161-170.

28. Kunkel, S. L., S. W. Chensue, and S. H. Phan. 1986. Prostaglandins as endogenous mediators of interleukin 1 production. J. Immunol. 136:186-192.

29. Tannenbaum, C. S., and T. A. Hamilton. 1989. Lipopolysaccharide-in- duced gene expression in murine peritoneal macrophages is selectively suppressed by agents that elevate intracellular cAMP. J. Immunol. 142:1274-1280.

30. Ohmori, Y., G. Strassman, and T. A. Hamilton. 1990. cAMP differentially regulates expression of mRNA encoding IL- $\alpha$ and IL- $1 \beta$ in murine peritoneal macrophages. J. Immunol. 145:3333-3339.

31. Caput, D., B. Beutler, K. Hartog, R. Thayer, S. Brown-Shimer, and A. Cerami. 1986. Identification of a common nucleotide sequence in the 3 '-untrans lated region of mRNA molecules specifying inflammatory mediators. Proc. Natl. Acad. Sci. USA. 83:1670-1674.

32. Davies, P., P. J. Bailey, M. M. Goldenberg, and A. W. Ford-Hutchinson. 1984. The role of arachidonic acid oxygenation products in pain and inflammation. Annu. Rev. Immunol. 2:335-357.

33. Rosoff, P. M., N. Savage, and C. A. Dinarello. 1988. Interleukin-1 stimulates diacylglycerol production in $\mathrm{T}$ lymphocytes by a novel mechanism. Cell. 54:73-81.

34. Elias, J. A., A. D. Schreiber, K. Gustilo, P. Chien, M. D. Rossman, P. J. Lammie, and R. P. Daniele. 1985. Differential interleukin 1 elaboration by unfractionated and density fractionated human alveolar macrophages and blood monocytes: relationship to cell maturity. J. Immunol. 135:3198-3204.

35. Sassone-Corsi, P., J. Visvader, L. Ferland, P. L. Mellon, and I. M. Verma 1988. Induction of proto-oncogene fos transcription through the adenylate cyclase pathway: characterization of a cAMP-responsive element. Genes \& Dev. 2:1529-1538.

36. Muller, U., M. P. Roberts, D. A. Engel, W. Doerfler, and T. Shenk. 1989. Induction of transcription factor AP-1 by adenovirus E1A protein and CAMP. Genes \& Dev. 3:1991-2002.

37. Shirakawa, F. M. Chedid, J. Suttles, B. A. Pollok, and S. B. Mizel. 1989. Interleukin 1 and cyclic AMP induce $\alpha$ immunoglobulin light-chain expression via activation of an NF-кB-like DNA-binding protein. Mol. Cell. Biol. 9:959-964.

38. Lenardo, M. J., and D. Baltimore. 1989. NF-kB: a pleiotropic mediator of inducible and tissue-specific gene control. Cell. 58:227-229. 